\section{Anaplastic lymphoma tyrosine kinase oncogene in human cancer: gene aberrations, methods of detection and therapeutic potential}

\section{Rosalaura Sabetta, Monica Gargiulo, Marina Accardo, Federica Zito Marino, Renato Franco}

Pathology Unit, Second University of Naples, Naples, Italy

\begin{abstract}
Anaplastic lymphoma tyrosine kinase $(A L K)$ gene could be an attractive oncotarget in human cancers, since it is involved in several genetic alterations resulting in an aberrant activity of the receptor. To date, ALK-rearrangement represents a molecular target for the treatment of ALK-rearranged Non Small Cell Lung Cancer patients, who are highly sensitive to crizotinib, a specific inhibitor. ALK-rearranged patients treated with crizotinib show relevant clinical implications, however several different resistance mechanisms have been identified. Here we review various critical issues related to ALK-targeting therapy, including ALK gene aberrations, methods of detection, mechanism of acquired resistance and second-generation ALK inhibitors.
\end{abstract}

\section{Introduction}

Anaplastic lymphoma kinase $(A L K)$ gene maps on the short arm of chromosome 2 (2p23) and it encodes for a tyrosine kinase receptor (RTK). ALK is physiologically expressed only in the nervous system during embryogenesis and plays important roles in cellular proliferation and differentiation. In human adults, ALK protein is expressed exclusively in the pericytes of the brain and in rare scattered neuronal and endothelial cells. ${ }^{1,2}$ ALK displays the classical structural features of a RTK, with an extracellular domain, a single pass transmembrane region and an intracellular kinase domain. The extracellular segment contains specific domains including two MAM (meprin, A5 protein and receptor protein tyrosine phosphatase $\mathrm{mu}$ ) domains involved in cell-cell interactions, a LDLa (low-density lipoprotein class A) domain with still unclear functions, and a glycinerich segment. ${ }^{3}$ Previous studies showed that the midkine $(\mathrm{MK})$ and the pleiotrophin (PTN), two small heparin-binding growth factors implicated in neuronal development, act as ligands for ALK receptor. ALK leads to the activation of several different pathways, such as JAK/STAT3, RAS/MAPK, $\mathrm{PI} 3 \mathrm{~K} / \mathrm{AKT}$ and PLC- $\gamma$, implicated in cell proliferation, differentiation and survival. ${ }^{4,5}$ ALK was originally described in Anaplastic Large Cell Lymphoma (ALCL), involved in a translocation with the nucleophosmin (NPM) $(2 ; 5)$ (p23:q35) resulting in a chimaeric protein NPM-ALK. ${ }^{3}$ Subsequently, several other ALK gene alterations were described in different human malignancies, including neuroblastoma, anaplastic thyroid cancer and Non Small Cell Lung Cancer (NSCLC). $A L K$ gene aberrations, including the point mutations and the rearrangement, lead to a constitutive activation of the receptor resulting in an uncontrolled cellular proliferation, differentiation and survival.

\section{ALK gene aberrations in human cancer}

$A L K$ gene is involved in different genetic aberration, including rearrangements, activating point mutations and gene amplification. ALK gene alterations have been identified in several malignancies, including Anaplastic Non-Hodgkin's lymphoma, breast cancer, colorectal carcinoma, inflammatory myofibroblastic tumor, diffuse large B-Cell lymphoma, renal carcinomas, esophageal squamous cell carcinoma, anaplastic thyroid carcinoma, neuroblastoma, glioblastoma, Ewing's sarcoma, ovarian cancer, melanoma, and rhabdomyosarcoma (Table 1). . $^{3,6-41}$

ALK-rearrangement (ALK-R) was described for the first time in ALCL, subsequently ALK-fusion proteins and different fusion partners are identified in other tumor types. In NSCLC, ALK-R are reported with a frequency of $3-7 \%$ and patients harboring this alteration are sensitive to ALK specific inhibitors. Echinoderm microtube-associated protein-like 4 (EML4) gene, mapped in position $2 \mathrm{p} 21$, is the most frequent ALK fusion partner. EML4-ALK chimeric gene is generated by the small inversion within the short arm of chromosome 2 and it encodes for a fusion protein with the N-terminus of EML4 and the kinase domain of ALK. ${ }^{10,42}$ Other ALK fusion partners have been identified in NSCLC, including TRKfused gene (TFG), kinesin family member 5B (KIF5B) and kinesin light chain 1 (KLC1). ${ }^{11,13,43}$ ALK-R is frequently described in a subset of patients with NSCLC, particularly in male, young and never/light smoker patients. Furthermore, ALK-R is generally associated with adeno-
Correspondence: Renato Franco, Pathology Unit, Università della Campania 'Luigi Vanvitelli’, Via Luciano Armanni 20, 80100, Napoli, Italy.

Tel. +39.081.5664000.

E-mail: renato.franco@unicampania.it

Key words: Anaplastic lymphoma kinase, Target therapy, Non small cell lung cancer.

Contributions: RS and MG: have equally contributed to carried out the draft of the manuscript; MA: has critically revised the manuscript; FZM: has participated in design of the manuscript and coordinated to draft the manuscript. RF: has conceived the manuscript.

Conflict of interest: the authors declare no potential conflict of interest. This study has no funding source and no other involvement.

Received for publication: 17 May 2017. Revision received: 22 July 2017.

Accepted for publication: 23 July 2017.

This work is licensed under a Creative Commons Attribution 4.0 License (by-nc 4.0).

CC Copyright R. Sabetta et al., 2017

Licensee PAGEPress, Italy

Translational Medicine Reports 2017; 1:6803 doi:10.4081/tmr.6803

carcinoma histotype, especially in solid signet-ring cell and mucinous cribriform pattern. ${ }^{44,45}$ To date, NSCLC patients harboring ALK-R are treated with crizotinib, a specific inhibitor that acts through competitive binding to the ATP-binding pocket of the target kinases. This inhibitor was initially developed as a c-MET inhibitor, then its relevant activity in advanced NSCLC ALKpositive has been demonstrated. ${ }^{46,47}$ In 2011 , crizotinib was approved by the Food and Drug Administration (FDA) for the treatment of ALK-rearranged advanced NSCLCs.

In addition to the rearrangement, ALK gene could be involved also in mutations, especially in neuroblastoma more than 35 mutations have been currently described. The majority of ALK mutations occurred within the kinase domain more frequently in three hotspots amino acid residues such as F1174, F1245 and R1275. The frequency of these mutations is different between sporadic and familial cases, especially R 1275 mutations are frequently found in both sporadic and familial cases, conversely no germline mutations involving the F1174 or F1245 are described. ${ }^{28,48,49}$ Furthermore, other ALK point mutations are reported also in undifferentiated anaplastic thyroid cancer (ATC), in particular C3592T and G3602A mutations in exon 23 were found in approx- 
imately $11.11 \%$ of cases, leading a constitutive activation of RAS/MAPK and PI3K/AKT pathways. ${ }^{50}$

ALK gene could be involved also in an increase of the number of copies that could involve in a deregulated expression of ALK protein. ALK amplification (ALK-A) is a common genetic event in several cancers and it is often associated with a more aggressive behavior. ALK-A was described for the first time in neuroblastoma cell lines as a mechanism involved in tumorigenesis. Subsequently, ALK gene extra copies were found in several other cancers, such as NSCLC, ALCL, inflammatory breast cancers, pulmonary sarcomatoid carcinoma, rhabdomyosarcoma, carcinoma of the esophagus, adult renal cell carcinoma and hepatocellular carcinoma. ${ }^{51}$ Moreover, Bresler et al. showed that the human NBderived cell lines with ALK-A are sensitive to both crizotinib and TAE684, another selective ALK inhibitor. ${ }^{52}$ These findings suggest that ALK inhibitors could be used in the treatment of ALK-amplified patients. ALK gene copy number gain could be more frequently associated with the chromosome 2 polysomy, thus a correct analysis needs the discrimination of real ALK-A versus chromosome 2 polysomy through the use of a specific centromeric alpha-satellite probe (CEP2). The instability of chromosome 2 with an increased copy numbers of some regions represents a frequent event in cancer, leading to a deregulated expression of the gene located in this amplicon. For example, ALK and MYCN co-amplification has been reported in approximately 7$15 \%$ of NB. Moreover, a close connection between ALK and MYCN has been demonstrated in neuronal and NB cell lines, in fact ALK receptor activation could lead to the initiation of MYCN mRNA transcription. ${ }^{53}$ Finally, ALK gene extra copies could have a value in the context of ALK-targeting therapy.

\section{Assays for ALK aberrations detections: FISH, IHC and RT-PCR}

Several assays are currently used to analyze ALK alterations, including immunohistochemistry (IHC), fluorescent in situ hybridization (FISH) and polymerase chain reaction based techniques (PCR). Below we will briefly review these methods and their relative advantages and disadvantages.

\section{FISH assay}

FISH is used for the detection ALK-R through a break apart strategy including two probes labeled with different fluorocromes and designed for the telomeric and centromeric sides of the break points. ${ }^{54}$

ALK FISH analysis is positive when at least $15 \%$ of cells show the classic breakapart pattern with one fusion, one red, and one green signal or alternative pattern with one fusion and one single red signal. ${ }^{55}$

FISH test has some disadvantages, such as a high cost, a lengthy turn-around time. Moreover, FISH interpretations requires expertise and does not allow the identification of specific fusion partner. ${ }^{56-59}$ However FISH represents a precise and reliable method to detect ALK-R. In 2011, FDA validated FISH test as a gold standard for the

Table 1. $A L K$ gene aberrations in human cancer.

\begin{tabular}{|c|c|c|c|}
\hline ALK alterations & Tumor type and fusion partners & $\begin{array}{l}\text { ALK-alterations } \\
\text { frequency ( } \%)\end{array}$ & References \\
\hline \multirow[t]{13}{*}{ ALK- rearrangements } & $\begin{array}{l}\text { Anaplastic Non-Hodgkin’s Lymphoma (ALCL) } \\
\text { TPM3, TPM4, TFG, ATIC, CLTC, MSN, MYH9, ALO17 }\end{array}$ & $60-85$ & $(3,7-9)$ \\
\hline & $\begin{array}{c}\text { Non-Small Cell Lung Cancer } \\
\text { EML4, TFG, KLCl, KIKF5B }\end{array}$ & $3-7$ & $(6,10-13)$ \\
\hline & Breast Cancer & 2.4 & $(14,15)$ \\
\hline & Colorectal Carcinoma & 2.4 & (14) \\
\hline & EML4 & & \\
\hline & Inflammatory Myofibroblastic Tumor (IMT) & $\sim 50 \%$ & $(12,16-18)$ \\
\hline & CLTC, TPM3, TPM4, CLTC, CARS, ATIC, RANBP2, SEC31L1 & & \\
\hline & Diffuse large B-Cell Lymphoma & NA & $(19,20)$ \\
\hline & CLTC,NPM & & \\
\hline & Renal Carcinomas & & \\
\hline & EML4, TPM3 and BCL & NA & $(21-25)$ \\
\hline & Esophageal Squamous Cell Carcinoma & $\sim 20$ & $(26)$ \\
\hline & & & \\
\hline \multirow{8}{*}{ ALK- mutations } & $\begin{array}{c}\text { Anaplastic Thyroid Carcinoma } \\
\text { L1198F, G1201E }\end{array}$ & 11 & (27) \\
\hline & Neuroblastoma & $4-33$ & $(28)$ \\
\hline & F1174L & & \\
\hline & F1174I & & \\
\hline & $\mathrm{F} 1245 \mathrm{C}$ & & \\
\hline & F1245V & & \\
\hline & R1275Q & & \\
\hline & $\mathrm{R} 1275 \mathrm{Q}$ & & \\
\hline \multirow[t]{7}{*}{ ALK gene extra copies } & Neuroblastoma & $\sim 50$ & $(28,30,31)$ \\
\hline & Glioblastoma & NA & $(32,33)$ \\
\hline & Ewing's sarcoma & NA & $(34,35)$ \\
\hline & Ovarian cancer & $2-4$ & $(36)$ \\
\hline & Melanoma & 6.9 & $(37)$ \\
\hline & Rhabdomyosarcoma & 45 & $(38-40)$ \\
\hline & Extramedullary plasmacytoma & $\sim 2.2$ & (41) \\
\hline
\end{tabular}

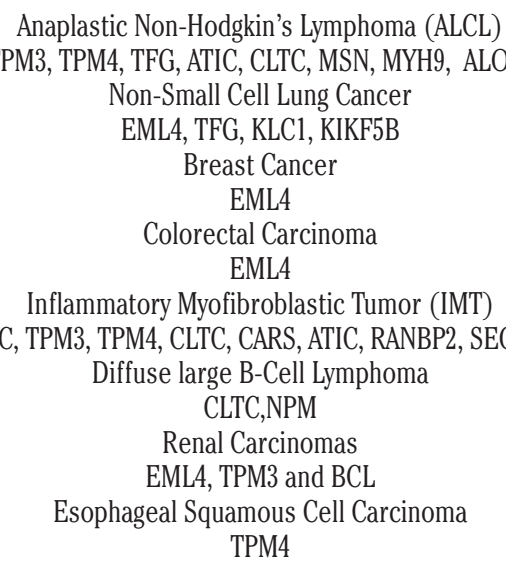


selection of ALK-rearranged advanced NSCLC patients eligible to the treatment with crizotinib. ${ }^{57,60}$

\section{IHC assay}

Immunohistochemical assay represents an easy technique routinely used in pathological diagnosis. IHC with antibody antiALK clone ALK1 is a gold standard assay to identify ALK protein in ALCL. However, the clone ALK1 was not adequate to detect ALK in NSCLC samples, therefore other antibodies have been proposed in last few years, including 5A4, and D5F3. ${ }^{61,62}$ Finally, in June 2015, ALK (D5F3) CDx Assay on the BenchMark XT platform with the Optiview Amplification Kit was approved for ALK detection in NSCLC patients. ALK D5F3 staining results were evaluated using a binary scoring system as positive or negative following the manufacturer's instructions. ${ }^{63}$

\section{PCR}

PCR-based techniques could be used to identify specific ALK fusion variants, particularly through the use of commercial kits containing the primers specific for most frequent fusion transcripts. ${ }^{59,60,64-66}$

PCR is extremely sensitive and specific, however it shows some disadvantages in the clinical practice, such as the loss of rare or novel translocations, RNA degradation and poor sample quality related to tissues that are formalin-fixed paraffin-embedded. ${ }^{67}$

\section{ALK target therapy and drug resistance in NSCLC}

ALK represents a molecular target in lung cancer treatment, particularly NSCLC patients harboring ALK-R that are treated with crizotinib and which resulted in greater improvement in global quality of life and when compared to chemotherapy. ${ }^{46,47}$

In August 2011, the impressively high rate of rapid objective responses to crizotinib has led to an accelerated approval of the drug for the treatment of ALK-positive patients with locally advanced or metastatic NSCLC.

Despite the initial sensitivity to crizotinib, ALK-rearranged patients frequently develop the acquired resistance. In literature, ALK-positive critzotinib-treated relapsed patients are reported and the middle time of relapse was approximately 4 to 34 months. ${ }^{68,69}$
To date, various resistance mechanisms to crizotinib have been identified, particularly two different types were describe including ALK-dependent and ALK-independent resistance. ${ }^{68,70}$

ALK-dependent mechanisms are associated to ALK gene alterations as copy number gain or mutations. On the contrary, ALK-independent resistance involves other mechanisms not associated with ALK gene, for example mutations occurrence in EGFR and KRAS gene, c-kit amplification, or histological shift (Table 2). ${ }^{68,69,71-74}$ Furthermore, some ALK-rearranged patients with a disease progression after crizotinib treatment showed two different resistance mechanisms in the same tumor. ${ }^{71}$

In this context, second-generation ALK inhibitors have been developed in order to overcome resistance to crizotinib, especially these new inhibitors have showed high efficacy against both the ALK secondary mutations and the ALK-independent resist-

Table 2. Mechanisms of Critzotinib resistance.

\begin{tabular}{lccc}
$\begin{array}{l}\text { Mechanism } \\
\text { of Crizotinib resistance }\end{array}$ & Major alterations & References \\
ALK dominant & ALK-point mutations & G1269A EML-ALK & $(68)$ \\
& & L1196M EML-ALK & $(68,69,71)$ \\
& & C1156Y EML-ALK & $(68,69,71)$ \\
& S1206Y EML-ALK & $(69,71,72)$ \\
& L1152R EML-ALK & $(73)$ \\
& & G1202R EML-ALK & $(69,72)$ \\
ALK non-dominant & ALK-copy number gain & 1151 Tins: Thr insertion & $(68)$ \\
& EGFR alterations & L585R amplification & $(68,69,73)$ \\
& KRAS mutations & G12C G12V & $(68)$ \\
& c-Kit & amplification & $(69)$ \\
\hline
\end{tabular}

Table 3. Characteristics of second-generation ALK inhibitors..

\begin{tabular}{|c|c|c|c|c|}
\hline Drugs & $\begin{array}{c}\text { Molecular targets other } \\
\text { than ALK }\end{array}$ & $\begin{array}{l}\text { Resistance mutations that } \\
\text { are sensitive to the dug }\end{array}$ & Current status & References \\
\hline Crizotinib & ROS1, MET, Ron and AXL & $\mathrm{L} 1198 \mathrm{~F}+\mathrm{C} 1156 \mathrm{Y}$ & FDA and EMA approved & (87) \\
\hline Ceritinib & IGF-1R, InsR and ROS1 & $\begin{array}{l}\text { L1196M, G1269A, S1206Y, F1245C, } \\
\text { I1171T (N), V1180L }\end{array}$ & FDA and EMA approved & (87) \\
\hline Alectinib & RET, GAK, LTK & $\begin{array}{l}\text { L1196M, G1269A, S1206Y, C1156Y, } \\
\text { F1147L, F1245C, L1152R, 1151T-ins }\end{array}$ & FDA approved & (87) \\
\hline Brigatinib & EGFR and ROS1 & G1269S, L1196M & Phase II/III & (87) \\
\hline Lorlatinib & ROS1 & G120R, G1269A & Phase I/II & (87) \\
\hline TSR011 & NTRK & L1196M & Phase I/II & \\
\hline ASP3026 & ROS1, ACK & L1196M & Phase I/II & \\
\hline X396 & MET & L1196M and C1156Y & Phase I/II & (88) \\
\hline Entrectinib & ROS1 and NTRK & L1196M and C1156Y & Phase I/II & \\
\hline CEP-28122/37440 & $\begin{array}{l}\text { CEP-28122: InsR, } \\
\text { IGF-R1 and c-MET; } \\
\text { CEP-37440: FAK }\end{array}$ & -- & Preclinical development and phase I & (89) \\
\hline
\end{tabular}


ance (Table 3). ${ }^{75-89}$

The first new generation of ALK inhibitor FDA-approved was Ceritinib (LDK378) that was recommended for the treatment of ALK-positive NSCLC patients who have recurrence or no longer respond to treatment to crizotinib. Clinical trials showed that previously patients treated with crizotinib had an overall response rate to ceritinib of $56 \%$, a median duration of response of 8.3 months and a median PFS of 6.9 months..$^{75,76}$ Then, FDA approved also alectinib (Alecensa) for the treatment of ALK-rearranged NSCLC patients with disease progression. ${ }^{77,78}$

Moreover, new generation of ALK inhibitors represent a glimmer for the treatment of advanced NSCLC especially those with brain metastases. ${ }^{79}$ In particular, Alectinib showed better central nervous system penetration compared with crizotinib, since it is not expelled from the intracranial environment. ${ }^{80,81}$ Moreover, one of the major advantages of these new drugs is the differential efficacy against the various ALK alterations, for example the gatekeeper mutations V1180L and I1171T that give resistance to alectinib but are sensitive to ceritinib. ${ }^{57,58}$

In the last years, other next-generation ALK inhibitors are in clinical development including brigatinib and lorlatinib. Recent studies showed the efficacy of lorlatinib (PF-06463922) in patients harboring G1202R ALK mutation that confers resistance to other next-generation ALK inhibitors, including ceritinib, alectinib and brigatinib. $^{82-85}$ Moreover, ALK positive patients with a disease progression after one or more ALK inhibitors, showed overall response rate of $46 \%$ and a median PFS of 11.4 months. ${ }^{54-86}$

\section{Conclusions}

ALK gene could represent an intriguing molecular target in several different human cancers. ALK-targeting therapy showed dramatic benefits, particularly in NSCLC, thus it would be desirable that the plethora of patients sensitive to ALK inhibitors might be expanded. Therefore, further studies are required to analyze other aberrations occurring in ALK gene, beyond the rearrangement. Finally, the management of ALK-rearranged NSCLC with disease progression due to resistance to crizotinib represents currently a critical issue in the clinical practice.

\section{References}

1. Motegi A, Fujimoto J, Kotani M, et al. Alk receptor tyrosine kinase promotes cell growth and neurite outgrowth. J Cell Sci 2004;1:3319-29.

2. Iwahara T, Fujimoto J, Wen D, et al. Molecular characterization of alk, a receptor tyrosine kinase expressed specifically in the ner 530 vous system. Oncogene 1997;30:439-44.

3. Morris SW, Kirstei MN, Valentine MB, et al. Fusion of a kinase gene, ALK, to a nucleolar protein gene, NPM, in nonHodgkin's lymphoma. Science 1994;263:1281-14.

4. Kadomatsu K, Muramatsu T. Midkine and pleiotrophin in neural development and cancer. CancerLett 2004;204:12743

5. Muramatsu T. Midkine and pleiotrophin: two related proteins involved in development, survival, inflammation and tumorigenesis. J Biochem 2002;132:359-371.

6. Hallberg B, Palmer RH. Mechanistic insight into ALK receptor tyrosine kinase in human cancer biology. Nat Rev Cancer 2013;13:685-700.

7. Delsol G, Ralfkiaer E, Stein H, et al. Anaplastic large cell lymphoma: primary systemic (T/null cell type). In: Jaffe ES, Harris NL, Stein H, eds. World Health Organization (WHO) Classification of Tumours: Pathology and Genetics of Tumours of Haematopoietic and Lymphoid Tissues. Lyon, France: IARC Press 2001;230-5.

8 Stein H, Foss HD, Durkop H, et al. CD30(+) anaplastic large cell lymphoma: a review of its histopathologic, genetic, and clinical features. Blood 2000;96:3681-95.

9. Pulford K, Lamant L, Espinos E, et al. The emerging normal and disease-related roles of anaplastic lymphoma kinase. Cell Mol Life Sci 2004;61:2939-53.

10. Soda M, Choi YL, Enomoto M, et al. Identification of the transforming EML4-ALK fusion gene in non-smallcell lung cancer. Nature 2007;448:5616.

11. Rikova K, Guo A, Zeng Q, et al. Global survey of phosphotyrosine signaling identifies oncogenic kinases in lung cancer. Cell 2007;131:1190-203.

12. Heuckmann JM, Balke-Want H, Malchers F, et al. Differential protein stability and ALK inhibitor sensitivity of EML4-ALK fusion variants. Clin Cancer Res 2012;18:4682-90.

13. Takeuchi K, Choi YL, Togashi Y, et al. KIF5B-ALK, a novel fusion oncokinase identified by an immunohistochemistry-based diagnostic system for ALK positive lung cancer. Clin Cancer Res 2009;15:3143-9.

14. Lin E, Li L, Guan Y, et al. Exon array profiling detects EML4-ALK fusion in breast, colorectal, and non-small cell lung cancers. Mol Cancer Res 2009; 7:1466-76.

15. Robertson FM, Petricoin Iii EF, Van Laere SJ, et al. Presence of anaplastic lymphoma kinase in inflammatory breast cancer. Springerplus 2013;2:497.

16. Cook JR, Dehner LP, Collins MH, et al. Anaplastic lymphoma kinase (ALK) expression in the inflammatory myofibroblastic tumor: a comparative immunohistochemical study. Am J Surg Pathol 2001;25:1364-71.

17. Gleason BC, Hornick JL. Inflammatory myofibroblastic tumours: where are we now? J Clin Pathol 2008;61:428-37.

18. Coffin CM, Patel A, Perkins S, et al. ALK1 and p80 expression and chromosomal rearrangements involving $2 \mathrm{p} 23$ in inflammatory myofibroblastic tumor. Mod Pathol 2001;14:569-76.

19. Gascoyne RD, Lamant L, MartinSubero JI, et al. ALK positive diffuse large B-cell lymphoma is associated with Clathrin-ALK rearrangements: report of 6 cases. Blood 2003;102:2568-73.

20. Laurent C, Do C, Gascoyne RD, et al. Anaplastic lymphoma kinase-positive diffuse large B-cell lymphoma: a rare clinicopathologic entity with poor prognosis. J Clin Oncol 2009;27:4211-6.

21. Grzelinski M, Steinberg F, Martens T, et al. Enhanced antitumorigenic effects in glioblastoma on double targeting of pleiotrophin and its receptor ALK. Neoplasia 2009;11:145-56.

22. Debelenko LV, Raimondi SC, Daw N, et al. Renal cell carcinoma with novel VCL-ALK fusion: new representative of ALK-associated tumor spectrum. Mod Pathol 2011;24:430-42.

23. Mariño-Enríquez $\mathrm{A}, \mathrm{Ou} \mathrm{WB}$, Weldon $\mathrm{CB}$, et al. ALK rearrangement in sickle cell trait-associated renal medullary carcinoma. Genes Chromosomes Cancer 2011;50:146-53.

24. Sukov WR, Hodge JC, Lohse CM, et al. ALK alterations in adult renal cell carcinoma: frequency, clinicopathologic features and outcome in a large series of consecutively treated patients. Mod Pathol 2012;25:1516-25.

25. Sugawara E, Togashi Y, Kuroda N, et al. Identification of anaplastic lymphoma kinase fusions in renal cancer: largescale immunohistochemical screening by the intercalated antibody-enhanced 
polymer method. Cancer 2012;118:4427-36.

26. Du XL, Hu H, Lin DC, et al. Proteomic profiling of proteins dysregulted in Chinese esophageal squamous cell carcinoma. J Mol Med 2007;85:863-75.

27. Murugan AK, Xing M. Anaplastic thyroid cancers harbor novel oncogenic mutations of the ALK gene. Cancer Res 2011;71:4403-11.

28. Mosse YP, Laudenslager M, Longo L et al. Identification of ALK as a major familial neuroblastoma predisposition gene. Nature 2008;455:930-5.

29. Ning H, Mitsui H, Wang CQ, et al. Identification of anaplastic lymphoma kinase as a potential therapeutic target in Basal Cell Carcinoma. Oncotarget 2013;4:2237-48.

30. Lamant L, Pulford K, Bischof D, et al. Expression of the ALK tyrosine kinase gene in neuroblastoma. Am J Pathol 2000;156:1711-21.

31. Wang M, Zhou C, Sun Q, et al. ALK amplification and protein expression predict inferior prognosis in neuroblastomas. Exp Mol Pathol 2013;95:12430.

32. Bilsland J G, Wheeldon A, Mead A, et al. Behavioral and neurochemical alterations in mice deficient in anaplastic lymphoma kinase suggest therapeutic potential for psychiatric indications. N e u rop s y h o pharma cology 2008;33:685-700.

33. Hurley SP, Clary D, Copie V, Lefcort F. Anaplastic lymphoma kinase is dynamically expressed on subsets of motor neurons and in the peripheral nervous system. J. Comp. Neurol 2006;495:20212.

34. Dirks WG, Fahnrich S, Lis Y, et al. Expression and functional analysis of the anaplastic lymphoma kinase (ALK) gene in tumor cell lines. Int $\mathrm{J}$ Cancer 2002;100:49-56.

35. Li XQ, Hisaoka M, Shi DR, et al. Expression of anaplastic lymphoma kinase in soft tissue tumors an immunohistochemical and molecular study of 249 cases. Hum Pathol 2004;35:711-21.

36. Ren H, Tan ZP, Zhu X, et al. Identification of anaplastic lymphoma kinase as a potential therapeutic target in ovarian cancer. Cancer Res 2012;72:3312-23.

37. Niu HT, Zhou QM, Wang F, et al. Identification of anaplastic lymphoma kinase break points and oncogenic mutation profiles in acral/mucosal melanomas. Pigment Cell Melanoma Res 2013;26:646-53.

38. Pillay K, Govender D, Chetty R. ALK protein expression in rhabdomyosarcomas. Histopathology 2002;41:461-7.
39. Corao DA, Biegel JA, Coffin CM, et al. ALK expression in rhabdomyosarcomas: correlation with histologic subtype and fusion status. Pediatr Dev Pathol 2009; 12:275-83.

40. Bonvini P, Zin A, Alaggio R, et al. High ALK mRNA expression has a negative prognostic significance in rhabdomyosarcoma. Br J Cancer 2013;109:308491.

41. Wang WY, Gu L, Liu WP, et al. ALK positive extramedullary plasmacytoma with expression of the CLTC-ALK fusion transcript. Pathol Res Pract 2011;207:587-91.

42. Carén H, Abel F, Kogner P, MartinssonT. High incidence of DNA mutations and gene amplification of the ALK gene in advanced sporadic neuroblastoma tumours. Biochem. J 2008;416:153-159.

43. Togashi Y, Soda M, Sakata S, et al. KLC1-ALK: A novel fusion in lung cancer identified using a formalin-fixed paraffin-embedded tissue only. PLoS One 2012;7:e31323.

44. Janku F, Stewart DJ, Kurzrock R. Targeted therapy in non-small-cell lung cancer - is it becoming a reality? Nat. Rev. Clin. Oncol 2010;7:401-14.

45. Yoshida A, Tsuta K, Nakamura H et al. Comprehensive histologic analysis of ALK-rearranged lung carcinomas. Am J Surg Pathol 2011;35:1126-234.

46. Kwak EL, Bang YJ, Camidge DR, et al. Anaplastic lymphoma kinase inhibition in nonsmall-cell lung cancer. N Engl J Med 2011;364:588.

47. Kim DW, Ahn MJ, Shi Y, et al. Results of a global phase II study with crizotinib in advanced ALK-positive nonsmall cell lung cancer (NSCLC). J Clin Oncol 2012;30:32-3.

48. Janoueix-Lerosey I, Lequin D, Brugieres L et al. Somatic and germline activating mutations of the ALK kinase receptor in neuroblastoma. Nature 2008;455:967-70.

49. George RE, Sanda T, Hanna M et al. Activating mutations in ALK provide a therapeutic target in neuroblastoma. Nature 2008;455:975-8.

50. Avaniyapuram KM, Mingzhao X. Anaplastic Thyroid Cancers Harbor Novel Oncogenic Mutations of the ALK Gene Cancer Res 2011;71:4403-11.

51. Zito Marino F, Rocco G, Morabito A, et al. A new look at the ALK gene in cancer: copy number gain and amplification Expert review of anticancer therapy. IERY 2016;16:493-502

52. Bresler SC, Wood AC, Haglund EA, et al. Differential inhibitor sensitivity of anaplastic lymphoma kinase variants found in neuroblastoma. Sci Transl Med 2011;3:108ra114.

53. Schönherr C, Ruuth K, Kamaraj S, et al. Anaplastic Lymphoma kinase (ALK) regulates initiation of transcription of MYCN in neuroblastoma cells. Oncogene. 2012;13:5193-200.

54. Murakami Y, MitsudomimT, Yatabe Y. A screening method of the ALK fusion gene in NSCLC. Front Oncol 2012;2:24.

55. Yi E, Boland JM, Maleszewski JJ, et al. Correlation of IHC and FISH for ALK gene rearrangement in non-small cell lung carcinoma: IHC score algorithm for FISH. J Thorac Oncol 2011;6:45965.

56. Li Y, Pan Y, Wang R, et al. ALKrearranged lung cancer in Chinese: a comprehensive assessment of clinicopathology, IHC, FISH and RT-PCR. PLoS One 2013;8:e69016.

57. Lira ME, Kim TM, Huang D, et al. Multiplexed gene expression and fusion transcript analysis to detect ALK fusions in lung cancer. J Mol Diagn 2013;15:51-61.

58. Wu YC, Chang IC, Wang CL, et al. Comparison of IHC, FISH and RT-PCR methods for detection of ALK rearrangements in 312 non-small cell lung cancer patients in Taiwan. PLoS One 2013;8:e70839.

59. Lamant L, Meggetto F, al Saati T, et al. High incidence of the $\mathrm{t}(2 ; 5)(\mathrm{p} 23 ; \mathrm{q} 35)$ translocation in anaplastic large cell lymphoma and its lack of detection in Hodgkin's disease. Comparison of cytogenetic analysis, reverse transcriptase polymerase chain reaction, and $\mathrm{P}-80$ immunostaining. Blood 1996;87:28491.

60. Rodney ES, Moiz V, Kim M, et al. ALK-rearrangements and testing methods in non-small cell lung cancer: a review. Genes Cancer 2014;5:1-14.

61. Mino-Kenudson M, Chirieac LR, Law $\mathrm{K}$, et al. A novel, highly sensitive antibody allows for the routine detection of ALK-rearranged lung adenocarcinomas by standard immunohistochemistry. Clin Cancer Res 2010;16:1561-71.

62. Thunnissen E, Bubendorf L, Dietel M, et al. EML4-ALK testing in non-small cell carcinomas of the lung: a review with recommendations. Virchows Arch 2012;461:245-57.

63. Marchetti A, Di Lorito A, Pace MV, et al. ALK Protein Analysis by IHC Staining after Recent Regulatory Changes: A Comparison of Two Widely Used Approaches, Revision of the Literature, and a New Testing $\begin{array}{lll}\text { Algorithm. } & \mathrm{J} \text { Thorac }\end{array}$ 
Oncol 2016;11:487-95.

64. Shaw AT, Yeap BY, Mino-Kenudson M, et al. Clinical features and outcome of patients with non-small-cell lung cancer who harbor EML4-ALK. J Clin Oncol 2009;27:4247-53.

65. Zhang YG, Jin ML, Li L, et al. Evaluation of ALK rearrangement in Chinese non-small cell lung cancer using FISH, immunohistochemistry, and real-time quantitative RT- PCR on paraffin-embedded tissues. PLoS One 2013;8:e64821.

66. Wang R, Pan Y, Li C, et al. The use of quantitative real-time reverse transcriptase PCR for 5' and 3' portions of ALK transcripts to detect ALK rearrangements in lung cancers. Clin Cancer Res 2012;18:4725-32.

67. Andreozzi A, Crinò L, Gridelli C, et al. Raccomandazioni per l'analisi dei riarrangiamenti del gene ALK nel carcinoma polmonare non a piccole cellule AIOM. SIAPEC-IAP.

68. Doebele RC, Pilling AB, Aisner DL, et al. Mechanisms of resistance to crizotinib in patients with ALK gene rearranged non-small cell lung cancer. Clin Cancer Res 2012;18:1472-1482.

69. Katayama R, Shaw AT, Khan TM, et al. Mechanisms of acquired crizotinib resistance in ALK-rearranged lung Cancers. Sci Transl Med. 2012;4:120ra17.

70. Kim S, Kim TM, Kim DW, et al. Heterogeneity of genetic changes associated with acquired crizotinib resistance in ALK-rearranged lung cancer. J Thorac Oncol 2013;8:415-422.

71. Choi YL, Soda M, Yamashita Y, et al. EML4-ALK mutations in lung cancer that confer resistance to ALK inhibitors. N Engl J Med 2010;363:1734-9.

72. Sun HY1, Ji FQ. A molecular dynamics investigation on the crizotinib resistance mechanism of $\mathrm{C} 1156 \mathrm{Y}$ mutation in ALK. Biochem Biophys Res Commun 2012;423:319-24.

73. Sasaki T, Koivunen J, Ogino A, et al. A novel ALK secondary mutation and EGFR signaling cause resistance to ALK kinase inhibitors. Cancer Res. 2011;71:6051-60.

74. Ji C, Zhang L, Cheng Y, Patel R, et al. Induction of autophagy contributes to crizotinib resistance in ALKpositive lung cancer. Cancer Biol Ther 2014;15:570-7.

75. Kim DW, Mehra R, Tan DS, et al. Activity and safety of ceritinib in patients with ALK-rearranged nonsmall-cell lung cancer (ASCEND1): updated results from the multicentre, open-label, phase 1 trial. The lancet oncology 2016;17:452-63.

76. Shaw AT, Engelman JA. Ceritinib in ALK-rearranged non-small-cell lung cancer. The New England journal of medicine 2014;370:2537-9.77. O u SH, Ahn JS, De Petris L, et al. Alectinib in Crizotinib-Refractory ALKRearranged Non-Small-Cell Lung Cancer: A Phase II Global Study. Journal of clinical oncology official journal of the American Society of Clinical Oncology 2016;34:661-8.

78. Shaw AT, Gandhi L, Gadgeel S, et al. Alectinib in ALKpositive, crizotinibresistant, non-small-cell lung cancer: a single-group, multicentre, phase 2 trial. Lancet Oncol 2016;17:234-42.

79. Zhang I, Zaorsky NG, Palmer JD, et al. Targeting brain metastases in ALKrearranged non-small-cell lung cancer. Lancet Oncol 2015;16:e510-21.

80. Gadgeel SM, Gandhi L, Riely GJ, et al. Safety and activity of alectinib against systemic disease and brain metastases in patients with crizotinib-resistant ALKrearranged non-small-cell lung cancer (AF-002JG): results from the dose-finding portion of a phase $1 / 2$ study. Lancet Oncol 2014;15:1119-28.

81. Kodama T, Hasegawa M, Takanashi K, et al. Antitumor activity of the selective ALK inhibitor alectinib in models of intracranial metastases. Cancer Chemother Pharmacol 2014;74:1023-8.
82. Rosell R, Karachaliou N, Wolf J, Ou SH. ALK and ROS1 non-small-cell lung cancer: two molecular subgroups sensitive to targeted therapy. Lancet Respiratory Med 2014;2:966-8.

83. Katayama R, Friboulet L, Koike S, et al. Two novel ALK mutations mediate acquired resistance to the next-generation ALK inhibitor alectinib. Clin Cancer Res 2014;20:5686-96.

84. Zou HY, Li Q, Engstrom LD, et al. PF06463922 is a potent and selective nextgeneration ROS1/ALK inhibitor capable of blocking crizotinib-resistant ROS1 mutations. Proc Natl Acad Sci USA 2015;112:3493-8.

85. Zou HY, Friboulet L, Kodack DP, et al. PF-06463922, an ALK/ROS1 Inhibitor, Overcomes Resistance to First and Second Generation ALK Inhibitors in Preclinical Models. Cancer Cell 2015;28:70-81.

86. Solomon B, Bauer T, Felip E, et al. Safety and efficacy of lorlatinib (PF06463922) from the dose-escalation component of a study in patients with advanced ALK+ or ROS1+ non-small cell lung cancer (NSCLC). J Clin Oncol 2016;2016:34.

87. Passaro A, Lazzari C, Karachaliou N, et al. Personalized treatment in advanced ALK-positive nonsmall cell lung cancer: from bench to clinical practice. Oncotargets Ther 2016;9:6361-76.

88. Lovly CM, Heuckmann JM, de Stanchina E, et al. Insights into ALKdriven cancers revealed through development of novel ALK tyrosine kinase inhibitors. Cancer Res 2011;71:492031.

89. Cheng M, Quail MR, Gingrich DE, et al. CEP-28122, a highly potent and selective orally active inhibitor of anaplastic lymphoma kinase with antitumor activity in experimental models of human cancers. Mol Cancer Ther 2012;11:670-9. 